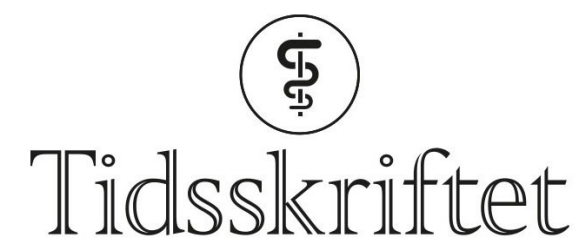

DEN NORSKE LEGEFORENING

\title{
Bør leses
}

ANMELDELSER

KARL BJøRNAR ALSTADHAUG

Overlege, Nevrologisk avdeling

Nordlandssykehuset i Bod $\varnothing$

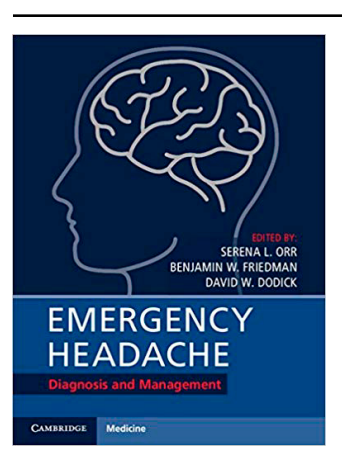

Serena L. Orr, Benjamin W. Friedman, David W. Dodick, red.

Emergency Headache

Diagnosis and Management.172 s, tab, ill. Cambridge: Cambridge University Press, 2017. Pris USD 58

ISBN 978-1-107-17720-8

Etter å ha jobbet på en middels stor nevrologisk avdeling i mange år har jeg erfart at pasienter innlagt med hodepine gjerne får tatt et CT caput, blir spinalpunktert, og utskrevet med diagnosen hodepine, ICD-10 kode R51. Behandlingen blir deretter, og det avtales sjeldent kontroll.

Hodepine er en svært hyppig årsak til akuttinnleggelse på sykehus. Fordi noen sekundære former kan være livstruende, fokuserer man på å utelukke disse først. Er rutinene for dette der du jobber gode nok, og er diagnostikk og håndtering av primære hodepiner tilfredsstillende? Denne boken vil gi deg mange svar, og den tar mål av seg å være et nyttig hjelpemiddel med evidensbasert tilnærming. Det ønskes velkommen.

Boken har forfattere fra ulike land, og eksperter både innen nevrologi og akuttmedisin er representert. Til tross for det begrensede sidetallet dekker boken feltet bredt og relativt detaljert i sine 14 kapitler. Informasjonsmengden er langt større enn det som trengs for de fleste leger i et akuttmottak, og således er dette ingen tradisjonell håndbok, mer en klassisk lærebok. Det er en kjensgjerning at kunnskapsgrunnlaget for håndtering av ulike hodepiner i nødhjelpssituasjon er noe magert, noe som gjentas en rekke ganger i boken, og derfor blir en del anbefalinger generelle. Dessuten vises det til enkelte behandlinger som det ikke er tradisjon for i Norge. En korrekt diagnose er imidlertid beste utgangspunkt for 
riktig behandling.

Boken er godt skrevet, og innholdet er i stor grad nyansert og veldokumentert (725 referanser). Den er nok for omfattende for studenter, og den kan bli for akademisk for mange underordnede leger som allerede er i sving i akuttmottak (turnusleger og leger i spesialisering). Jeg er redd for at boken først om fremst vil bli lest av de som allerede er spesielt interesserte i hodepine, og at den derfor ikke vil bidra til å endre praksis der det trengs. Den har imidlertid potensiale til å kunne redusere antallet pasienter som blir utskrevet med R51-diagnose, unngå gjeninnleggelser av pasienter med primære hodepiner, og ikke minst til å forhindre at livstruende tilstander blir oversett. Boken anbefales derfor til alle som er involvert i diagnostikk og behandling av pasienter med hodepine i et akuttmottak.

Publisert: 11. mars 2019. Tidsskr Nor Legeforen. DOI:10.4045/tidsskr.18.0940

(C) Tidsskrift for Den norske legeforening 2020. Lastet ned fra tidsskriftet.no 